\title{
Reflections from a friend of Polish anti-tobacco campaigns
}

\author{
Judith Watt \\ The first coordinator of the UK No Smoking Day campaign, UK
}

ADDRESS FOR CORRESPONDENCE: Judith Watt, Board Member, Framework Convention Alliance, Rue de la Fontaine 2 Case Postale 3484 CH-1211 Geneva 3, Switzerland, e-mail: judith.watt@protocolman.net

My first encounter with Polish anti-tobacco campaigns took place not in Poland but in Moscow, in the last year of the Soviet Union. In March 1991, I was privileged to be invited by UICC to help deliver a training programme on tobacco control for 13 central and eastern European countries. The driving force behind the event was Prof. Witold Zatoński, with support from our host Prof. David Zaridze, Director of the Russian Institute of Carcinogenesis. At that time, I was still a relative newcomer to tobacco control, having organised three annual No Smoking Day campaigns in the UK. Professor Zatoński was planning the first Great Polish Smokeout for November 1991 and his ambition was to have as many other central and eastern European countries as possible join in with their own national campaigns at the same time. Of course, by 1991 Poland was already experienced in running public education campaigns on smoking as part of their comprehensive approach to tobacco control, underpinned by population research and systematic evaluation. The same was not true for the other countries in the region and the reaction to the training programme ranged from highly enthusiastic to highly sceptical. I recall one Russian participant proposing that since not all smokers died of lung cancer, our objective should be to determine what pre-disposes some smokers to disease, so they could be prevented from smoking while everyone else could carry on smoking without risk. Stimulated by the Moscow training and with ongoing encouragement from Poland, that year saw a big increase in anti-smoking campaigning across the region. The following year, many of the lead organisers from central and eastern Europe met with organisers from western Europe for the first time at a conference in London to exchange experiences and ideas for future improvements.
Thanks to the talented leadership in Poland, their campaigns were well-executed and well-evaluated. The 1992 Great Polish Smokeout was a particular success. A national newspaper, "Gazeta Wyborcza", provided weeks of free media coverage on the hazards of smoking and advice on how to quit with a quit-and-win style competition that attracted over 300,000 smokers to enter. As the top 20 prizes were a week-long trip to Rome and a private audience with Pope John Paul II, it is hardly surprising so many people entered. I was thrilled to be invited to join the winners of the competition on the trip to Rome in May 1993 together with members of Prof. Zatoński's team, sponsors and journalists. We set off in a coach with two drivers and travelled non-stop from Warsaw to Rome in 36 hours. Arriving around 6pm at the Polish convent on the outskirts of Rome where we would be staying, we were greeted by several nuns with the urgent message that we were to meet the Pope that evening instead of later in the week. Suddenly, all the travel-weary passengers ran to get changed into smart clothes and soon we were back in the coach and heading into the Vatican. Waved through by the Swiss Guards, we drove straight into the Vatican and were ushered into a very grand reception room with two other groups of Polish pilgrims. It was an extraordinary experience when the Pope arrived and led everyone in singing Polish folk songs and prayers. Later in the week, I accompanied Prof. Zatonski to a meeting with the President of Pontifical Council for the Pastoral Care of Health Care Workers, Cardinal Fiorenzo Angelini, who was effectively the Vatican's global Minister of Health. As we were waiting for him to arrive, I looked around the richly-decorated meeting room. In the corner was a very ornate silver ornament, about a metre high. On closer inspection, I realised it was a giant ashtray with an engraved 


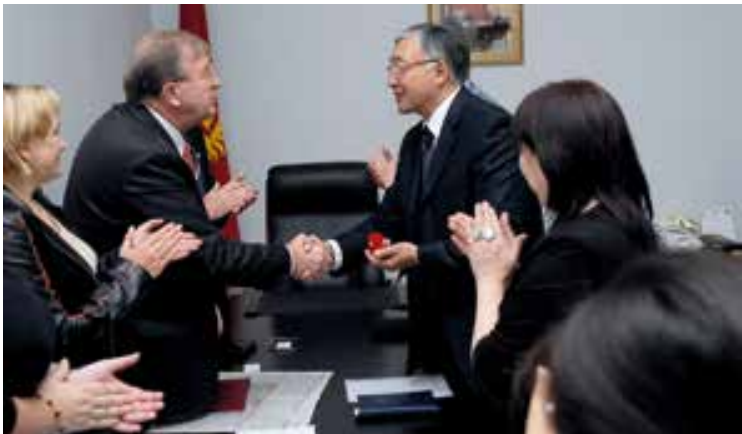

FIG 1. Professor Witold Zatoński awards the 'Golden Lungs' Honorary Award of the Health Promotion Foundation to the Kyrgyz Minister of Health. Health Promotion Foundation's training for medical doctors in treatment of tobacco dependence. Bishkek, Kyrgyzstan, October 2008

plaque showing it had been donated by Philip Morris. In the meeting, Prof. Zatoński put the case for the Catholic Church to provide leadership on reducing tobacco use, to both improve health and reduce poverty; and we discussed the possible avenues the church could use to encourage smokers to quit.

Over the following 20 years, I was lucky enough to work closely with Prof. Zatoński and his team on many occasions and on many initiatives. Thanks to Prof. Zatoński's standing in Poland, he was always able to open doors to important people, whether in government, media, business; and to mix the serious business of tobacco control with interesting experiences. When we

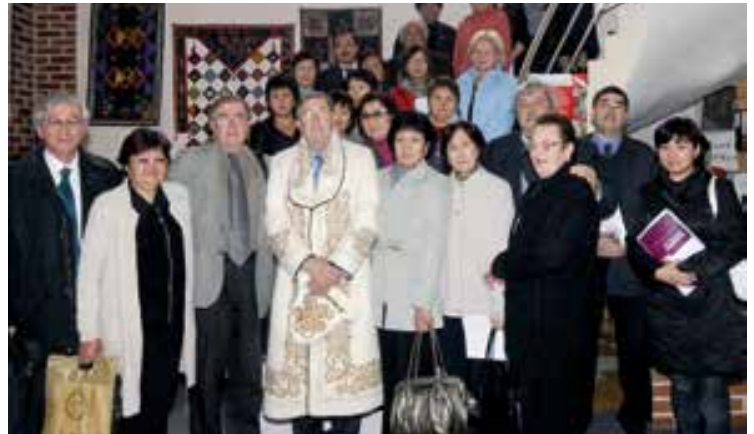

FIG 2. Polish team with Kyrgyz training participants. Professor Witold Zatoński is wearing a traditional Kyrgyz coat he received from the hosts. Health Promotion Foundation's training for medical doctors in treatment of tobacco dependence. Bishkek, Kyrgyzstan, October 2008

organised a high-level political mission from Kazakhstan to come to Warsaw for intensive briefings on tobacco control strategy with Polish politicians, scientists and advocates, the programme included a visit to the Presidential Palace and an opportunity to sit at the table where the Warsaw Pact was signed. The remarkable reduction in tobacco use in Poland over the last $30+$ years is testament to the remarkable people who have dedicated their lives to making that happen. It has been an honour to walk in their footsteps along the way.

\section{DISCLOSURE}

Author reports no conflict of interest. 